\title{
COMPETENCE TO PLEAD GUILTY: A NEW STANDARD
}

In Sieling v. Eyman, ${ }^{1}$ the Ninth Circuit Court of Appeals held that a court inay not accept a plea of guilty froin a criminal defendant who has been found competent to stand trial unless it also determines that he is competent to make the waiver of constitutional rights inherent in a guilty plea. ${ }^{2}$ Gilbert Sieling was charged with inultiple counts of assault with intent to commit murder and assault with a deadly weapon. ${ }^{3}$ After Sieling entered his plea of not guilty, the Arizona trial court granted defense counsel's motion for a pretrial competency hearing under Rule 250 of the Arizona Rules of Criminal Procedure. ${ }^{4}$ The court appointed two psychiatrists to examine Sieling.

1. 478 F.2d 211 (9th Cir. 1973).

HEREINAFTER THE FOLLOWING CITATIONS WILL BE USED IN THIS NOTE:

S. BRAKEL \& R. Rock, THE MeNtaliy Disabled AND the LAW (19T1) [hereinafter cited as Brakel \& RocK];

H. Wethofen, Mental Disorder as a Criminal Defense (1954) thereinafter cited as Wentofen].

2. The constitutional rights identified by the court as being waived by a guilty plea were those cited in Boykin v. Alabama, 395 U.S. 238, 243 (1969): the fifth amendment right against compulsory self-incrimination and the sixth amendment rights to trial by jury and to the confrontation of witnesses. 478 F.2d at 214. However, it is noted in Heberling, Judicial Review of the Guilty Plea, 7 Lincoln L. REv. 137, 187 (1973), that a fifth amendment waiver is no longer essential to a valid guilty plea because in North Carolina v. Alford, 400 U.S. 25 (1970), the Supreme Court lield that a trial court may accept a guilty plea accompanied by protestations of innocence if there is strong evidence of actual guilt. See also Comment, The Guilty Plea as a Waiver of Rights and as an Admission of Guilt, 44 TEMPLE L.Q. 540 (1971). In addition, it is frequently stated that a guilty plea also constitutes a waiver of all nonjnrisdictional defects and defenses, see, e.g., Hughes v. United States, 371 F.2d 694, 696 (8th Cir. 1967), including earlier violations of the defendant's constitutional rights unless the infringements motivated the guilty plea. Briley v. Wilson, 376 F.2d 802 (9th Cir. 1967). Cf. McMann v. Richardson, 397 U.S. 759 (1970). See generally Bishop, Waivers in Pleas of Guilty, 60 F.R.D. 513 (1974).

3. 478 F.2d at 213.

4. ARIz. Rules of Criminal Procedure, rule 250 (1956):

Examination of defendant's mental condition prior to or during trial . . . .

A. If before or during trial the conrt has reasonable ground to believe that the defendant, against whom an indictment has been found or an infornnation filed, is insane or mentally defective, to the extent that he is unable to understand the proceedings against him or to assist in his defense, the court shall immediately set a time for a hearing to determine the defendant's mental condition. ....

Rule 250 and its statutory counterpart, ARIz. REv. STAT. ANN. 13-1621A (1972), have been superseded by Rule 11.1 of the 1973 ARIz. RULEs OF CRIMINAI PROCEDURE, effective September 1, 1973. Rule 11.1 does not, however, make any substantive change. 
When the results of their examinations conflicted, it appointed a third; all three psychiatrists agreed that Sieling had been insane at the time of the offense. Upon the recommendation of two of the three psychiatrists, however, the court found the defendant competent to stand trial. One month after the competency hearing and shortly before the scheduled trial date, Sieling requested permission to change his plea. After conducting a routine inquiry into the voluntariness of Sieling's proposed plea and his understanding of the charge, the court accepted a plea of guilty to the counts of assault with a deadly weapon and granted the prosecutor's notion to dismiss the remaining counts in accordance with a "plea bargain." Sieling was sentenced to consecutive terms amounting to a 1naximum of sixteen years. ${ }^{5}$

Arguimg that, although competent to stand trial, he had been incompetent to plead guilty, Sieling petitioned the United States District Court for a writ of habeas corpus. ${ }^{6}$ The district court dismissed the petition ${ }^{7}$ and Sieling appealed. In a unanimous decision, the Ninth Circuit reversed. Relying on the Supreine Court's decision in Westbrook $v$. Arizona, ${ }^{8}$ which recognized a distinction between a defendant's coinpetence to stand trial and his competence to waive the right to counsel, the court held that neither Sieling's pretrial competency hearing nor the colloquy conducted before entry of his guilty plea sufficiently established his competence to make the "reasoned choice" which it deeined essential to the validity of a plea of guilty and the waiver of constitutional rights such a plea entails. ${ }^{9}$ The case was remanded to the district court with instructions to grant the writ of habeas corpus unless within sixty days the state trial court reviewed the psychiatric evidence in the record and specifically found Sieling competent to plead guilty under the "reasoned choice" standard adopted by the appellate court. ${ }^{10}$

5. 478 F.2d at 213 .

6. Id.

7. Id. The dismissal of Sieling's petition by the United States District Court for the District of Arizona was unreported.

8. 384 U.S. 150 (1966). See notes $45-48$ infra and accompanying text.

9. 478 F.2d at 214-15. It is important to note that Sieling does not require a finding of competence to plead guilty for every defendant who elects so to plead. Rather its rule is limited to cases in which the defendant's competence has been put in issue by an earlier competency hearing or when in some other manner a "substantial question" has arisen as to a defendant's mental capacity. Id. at 214.

10. Id. at 215-16. The standard adopted by the Sieling court was first suggested by Judge Hufstedler in her dissent in Schoeller v. Dunbar, 423 F.2d 1183, 1194 (9th Cir.), cert. denied, 400 U.S. 834 (1970): "A defendant is not competent to plead guilty if mental illness has substantially impaired his ability to make a reasoned choice among the alternatives presented to him and to understand the nature of the consequences of his plea." (Emphasis added.) 
The Ninth Circuit's opinion in Sieling represents an effort to determine the relationship between two heretofore distinct bodies of law, each accompanied by its own standards and procedures. The first of these concerns the defendant's mental capacity to be a party to criminal proceedings-his competence to stand trial. The second concerns the general validity of the entry of a guilty plea or a waiver of constitutional rights. Prior to the Supreme Court's decision in Westbrook, ${ }^{11}$ courts generally construed these bodies of law to serve separate and unrelated functions. The Sieling court, however, interpreted Westbrook both to recognize a conflict between them and to provide the means for its resolution. In order to assess the correctness of the Sieling decision and to undersand its implications, it is first necessary to examine briefly each of these bodies of law-the law of competence to stand trial and the law governing the validity of a waiver of constitutional rights or the entry of a guilty plea.

\section{Competence to Stand Trial-A Standard for All Purposes}

It has been held repeatedly that the criminal conviction of an incompetent defendant is a denial of the due process guaranteed by the fifth and fourteenth amendments. ${ }^{12}$ The cases so holding represent a constitutionalization $^{13}$ of the common law rule forbidding the trial,

11. See notes $45-48$ infra and accompanying text.

12. See, e.g., Pate v. Robinson, 383 U.S. 375 (1966); Bishop v. United States, 350 U.S. 961 (1956); Carroll v. Beto, 421 F.2d 1065 (5th Cir. 1970); Youtsey v. United States, 97 F. 937 (6th Cir. 1899); United States v. Gundelfinger, 98 F. Supp. 630 (W.D. Pa. 1951). See also 12 VilL. L. Rev. 655 (1967). But cf. Burt \& Norris, A Proposal for the Abolition of the Incompetency Plea, 40 U. CH. L. REv. 66, 75-76 (1972) (contending that due process should not require that a defendant be competent in order to be tried criminally and that indications by the Supreme Court to the contrary have been mere dicta).

13. See BRAKEL \& Rock 408; 1966 U. ILL. L.F. 773, 775. Aside from the constitutionalization of the common law rule, the development of constitutional law in the area of competence in the criminal process has centered upon procedural issues-Sieling thus represents a considerable change of foctus. These procedural developnients indicate that the defendant's competence is an absolute constitutional prerequisite to the validity of the proceedings; the issue of competence undercuts all other validating standards and procedures. First, the prohibition against subjecting an incompetent defendant to criminal proceedings is not subject to waiver, either voluntary, Seidner v. United States, 260 F.2d 732 (D.C. Cir. 1958), or involuntary, Taylor v. Umited States, 282 F.2d 16 (8th Cir. 1960), since such a waiver would by definition be invalid and its enforcement would deprive the incompetent defendant of most of the proteetion of the prohibition. Second, under Pate v. Robinson, 383 U.S. 375 (1966), a trial court must hold a hearing on its own initiative when facts come to its attention which raise a reasonable doubt as to the defendant's competence to proceed. Third, absent unusual circumstances, an express finding of competence as a result of such a hearing will have a res judicata effect sufficient to withstand collateral attack. Hanson v. United States, 406 F.2d 199 (9th Cir. 1969). See generally Schoeller 
sentencing, or execution of an incompetent person, ${ }^{14}$ and precluding the acceptance of an incoinpetent's guilty plea. ${ }^{15}$ Although variously stated, the common law standard of competence to stand trial essentially requires the capacity to understand the proceedings and to assist in one's own defense. ${ }^{16}$ The Supreme Court adopted this standard for

v. Dunbar, 423 F.2d 1183, 1186 (9th Cir.) (dissenting opinion), cert. denied, 400 U.S. 834 (1970) (general overview of the procedural aspects of the issue of competence to stand trial in federal habeas corpus proceedings; Annot., 7 A.L.R. Fed. 565 (1971). See also Burt \& Norris, supra note 12 (argument that it would be both constitutionally pernissible and in the best interests of defendants and the state to adapt the criminal process so that the defendant can be tried despite his incompetence).

Until the recent decision of Jackson v. Indiana, 406 U.S. 715 (1972), the problein of the disposition of defendants adjudged incompetent to stand trial strongly influenced the discussion of issues in this area. See, e.g., Eizenstat, Mental Competency to Stand Trial, 4 HARv. Civ. RIGHTS-Civ. LIB. L. REv. 379 (1969); Kaufinan, Evaluating Competency: Are Constitutional Deprivations Necessary?, 10 AM. CRM. L. REv. 465 (1972); Comment, Criminal Law-Insane Persons-Competency to Stand Trial, 59 MrCH. L. REV. 1078 (1961). The general practice-frequently required by statute, see BrAKEL \& Rock 415, Table 11.2, at 444-had been automatically to commit incompetent defendants to state hospitals for the criminally insane until they recovered sufficiently to proceed. See, e.g., A. MatTHews, Mental Disability and the Criminal LAw 133-34 (1970); Kaufman, supra at 466-67, 481; Note, Incompetency to Stand Trial, 81 HaRv. L. Rev. 454, 461-64 (1967). Thus, for many defendants a finding of in. competence to stand trial amounted to a sentence of life imprisonment without a trial. A. Matthews, supra at 138; Comment, supra at 1088-90. This practice caused some commentators to oppose raising the standard for competence. See, e.g., McGarry, Competency for Trial and Due Process via the State Hospital, 122 AM. J. PsYCHIATRY 623, 628 (1965); cf. Note, supra at 473 (recommending "narrow construction" of competence standards). It has led others to recommend the abolition of the incoinpetence plea altogether. See Burt \& Norris, supra note 12. The Supreme Court in Jackson eliminated much of this problem by holding that it is a violation of due process to hold a defendant who is incompetent to stand trial longer than is necessary to determine his prospects for improvement; a permanently incompetent defendant can be committed for an indefimite period only through proper civil proceedings. 406 U.S. at 738. See generally Comment, An End to Incompetency to Stand Trial, 13 SanTa Clara Law. 560 (1973); Note, Remedies for Individuals Wrongly Detained in State Mental Institutions Because of Their Incompetency to Stand Trial: Implementing Jackson v. Iudiana, 7 VALPARAIso U.L. REv. 203 (1973).

14. See, e.g., United States v. Chisolm, 149 F. 284 (5th Cir. 1906); Youtsey v. United States, 97 F. 937 (6th Cir. 1899); Howie v. State, 121 Miss. 197, 83 So. 158 (1919); State v. Smith, 25 N.M. 48, 176 P. 819 (1918); In re Buchanan, 129 Cal. 330, 61 P. 1120 (1900); WeIHOFEN 428-29; Note, Incompetency to Stand Trial, supra note 13 , at 454 .

15. See, e.g., Forthoffer v. Swope, 103 F.2d 707 (9th Cir. 1939); Youtsey v. United States, 97 F. 937, 940 (6th Cir. 1899); People v. Maynard, 347 Ill. 422, 179 N.E. 833 (1932); Jordan v. State, 124 Teun. 81, 135 S.W. 327 (1911); A. MatTHEws, supra note 13, at 19; WEIHOFEN 429.

16. WEIHOFEN 439. Few decisions elaborate the standards. It is unclear what degree of participation in the proceedings is required, that is, whether the defendant must be able to "conduct" his defense, as some variants of the common law standard state, see, e.g., State v. Severns, 184 Kan. 213, 219, 336 P.2d 447, 452 (1959); Ex parte 
the federal courts in $1959,{ }^{17}$ and this standard may represent a minimum for the states as well..$^{18}$ In any event, the law of most states embodies these requirements for competence to stand trial; nearly half of the

Hodges, 166 Tex. Crim. 433, 314 S.W.2d 581 (1958), or whether the defendant must merely be competent enough to be fairly defended. A frequently cited case, United States v. Chisolm, 149 F. 284 (5th Cir. 1906), the reported portion of which consists of an extended jury instruction, seems to adopt the former standard by requiring a defendant who is the master of his case. According to the Chisolm court, the defendant must have ". . . such poise of his faculties as will enable him to rationally and properly exercise all the rights which the law gives him in contesting an action." Id. at 287. However, since there seem to be no decisions holding a defendant to be incompetent because he is capable only of the much more passive "assistance," it is doubtful that such a high "ability to make one's own defense" standard is anywhere operative.

Some commentators have criticized the "understand and assist" standard of competence to stand trial because of the degree of participation it seems to allow:

[T]his term ["assist"] does not properly reflect the otherwise prevailing notion of the attorney-client relationship, according to which the accused is dominus litus and his attorney is but agent. Crucial decisions are . . . made by the accused and not by his attorney. H. Silving, ESSAYS IN MENTAL CAPACITY AND CRIMINAL CONDUCT 165 (1967).

Cf, Chernoff \& Schaffer, Defending the Mentally Ill: Ethical Quicksand, 10 AM. CRIM. L. REv. 505, 522 (1972). But see Burt \& Norris, supra note 12.

On the other hand, most commentators would allow preliminary defenses to be raised on behalf of an incompetent defendant even without his participation or assistance. See, e.g., Association of the Bar of the City of New York, Special CommitTEe on the Study of Commttment Procedures and the Law Relating to Incompetents, Second Report, Mental Illness, Due Process and the Crimtnal DefendANT 108-11, 115 (1968); Foote, A Comment on Pre-Trial Commitment of Criminal Defendants, 108 U. PA. L. REv. 832 (1960); Note, Incompetency to Stand Trial, supra note 13, at 467-68. Model Penal Code $\$ 4.06(3)$ (Proposed Official Draft 1962) provides:

The fact that the defendant is unfit to proceed does not preclude any legal objection to the prosecution which is susceptible to fair determination prior to trial and without the personal participation of the defendant.

This proposal was discussed with approval in Jackson v. Indiana, 406 U.S. 715, 74041 (1972).

17. Dusky v. United States, 362 U.S. 402 (1959). In adopting the "understand and assist" standard the court stated:

We also agree with the suggestion of the Solicitor General that it is not enough for the district judge to find that "the defendant [is] oriented to time and place and [has] some recollcction of events," but that the "test must be whether he has sufficient present ability to consult with his lawyer with a reasonable degree of rational understanding - and whether he has a rational as well as factual understanding of the proceedings against him." Id. (brackets in original).

18. In Noble v. Siglar, 351 F.2d 673 (8th Cir. 1965), the defendant secured review in federal court of his state court conviction by means of a petition for a writ of habeas corpus. The reviewing court held that since a federal constitutional right was involved - namely, the due process right of an incoinpetent defendant not to be tried later announced in Pate v. Robimson, 383 U.S. 375, 378 (1966) -the federal standard of competence to stand trial enunciated in Dusky should be used in reviewing the state court proceeding. 351 F.2d at 677. Contra, Ruffin v. Bailey, 354 F. Supp. 599 (E.D.N.C. 1966). See also 1966 U. IrL. L.F. 773, 778-79 (arguing that the Dusky standard applies to the states directly). 
states, including Arizona, have codified this common law "understand and assist" standard, ${ }^{19}$ and the statutes of inany of the remaining states, which provide simply that no accused nnay be tried who is "presently insane," 20 have been judicially interpreted to incorporate it. ${ }^{21}$ But while appellate courts attempt to police the distinction between mental illness in general and mental illness which impairs the ability to understand and assist, ${ }^{22}$ it is the consensus of commentators that the standards are loosely admimistered at the trial court level, in part due to their vagueness. ${ }^{23}$ And, although a few writers believe that the ability to make simple decisions is necessary to a correct finding of competence under the present "understand and assist" test, ${ }^{24}$ this common law

19. Brakel \& Rock, Table 11.2 , at $444-50$ (categorizing all state statutes as of 1970). See, e.g., ARIz. Rules of Criminal Procedure, rule 250 (1956); ConN. Gen. STAT. ANN. $\$ 54.40$ (1960), as amended $\$ 54.40$ (a) (Supp. 1973); VA. CODE ANN. 19.1-228 (1960), as amended (Supp. 1973). See also WelHofen 439.

20. See Brakel \& Rock, Table 11.2, at 444-50. See, e.g., Ala. Code tit. 15, § 426 (1959); Cal. Penal Code $\$ 1367$ (West 1970); Fla. R. CrIm. P. 1.210(a) (1968).

21. See, e.g., People v. Field, 108 Cal. App. 2d 496, 238 P.2d 1052 (1952); Brock v. State, 69 So. 2d 344 (Fla. 1954); Brakel \& Rock 410. A number of other states have recently changed their statutes from the "insanity" criterion to the common law test, patterning them after the Model Penal Code $\$ 4.04$ (Proposed Official Draft 1962) which incorporates the "understand and assist" standard: e.g., WIs. STAT. ANN. § 971.13 (1970), amending law originally passed as Ch. 631, \& 130, [1949] Wis. Laws; Mo. ANN. STAT. $\$ 552.020(1)$ (Supp. 1973), amending law originally passed as $\S 1$, [1883] Mo. Laws 79.

22. See, e.g., United States v. Chisholm, 149 F. 284 (5th Cir. 1906); State v. Severns, 184 Kan. 213, 336 P.2d 447 (1959); Ex parte Hodges, 166 Tex. Crim. 433, 314 S.W.2d 581 (1958).

23. Some commentators have stated that this judieial laxity results from the vagueness of the competence standards themselves. See Burt \& Norris, supra note 12 , at 92; Robey, Criteria for Competency to Stand Trial: A Checklist for Psychiatrists, 122 AM. J. PsychitrRY 616, 621 (1965); Coininent, Criminal Law, supra note 13, at 1082.

Others have indicated that the loose administration of the standards results from the fact that in most cases, a psyehiatrist's conclusion as to the presence or absence of psychosis will be considered determmative. See Brakel \& Rock 410; Note, Incompetency to Stand Trial, supra note 13, at 460 . See generally A. MaTtuews, supra note 13, ch. 3. According to Matthews, "The [psychiatrists'] reports are usually 'boiler plate' documents which pass muster only because the courts in fact routinely accept the conclusions of the doctors." Id. at 86; cf. Splitt v. United States, 364 F.2d 594, 597-98 (6th Cir. 1966), cert. denied, 385 U.S. 1019 (1967) (holding that an earlier release of a defendant from a meutal hospital because he had been found "without psychosis" amounted to the reinstatement of the presumption of sanity for the purpose of competence to stand trial).

Of course, courts may in fact rely heavily on the opinions of psychiatrists only because the standards are so vague as to leave the courts with no alternative method of determining competence.

24. See Robey, supra note 23, at 619 :

[The defendant] must decide with his lawyer upon a plea and approve the legal strategy to be used during the trial ....

$$
\text { ... Occasionally, during the course of a trial, the problem of waiver of }
$$


test itself is criticized for its lack of volitional elements. ${ }^{25}$

It seems generally to have been assumed that this common law standard of competence to stand trial serves as the standard for all purposes of the criminal proceedings. ${ }^{26}$ Thus, absent a subsequent change in the defendant's mental condition, a single finding of competence in a pretrial competency hearing has been understood to settle the issue of the defendant's competence to participate in all of the proceedings that follow. ${ }^{27}$ Most courts, however, have generally applied the common law "understand and assist" standard to the guilty plea without comment or critical analysis. ${ }^{28}$ In order to plead guilty, therefore, it has been required that a defendant must be capable of understanding the proceedings and assisting in his own defense, even though no defense is contemplated when a guilty plea is enacted. Before Westbrook, ${ }^{29}$ the defendant's capability of waiving his constitutional rights after he

rights arises, and the patient must have some ability to make simple decisions

in response to well-explained alternatives.

Cf. Note, Incompetency to Stand Trial, supra note 13, at 458.

25. See H. Silving, supra note 16; McGarry, supra note 13, at 628 (1965), in which the standard test is criticized for measuring only "knowledge or apperception," and failing to assess either "affect" (emotional state) or "the ability to act affirmatively" (volition).

26. See Wethofen 431; cf. Robey, supra note 23. But cf. Bell v. United States, 265 F. Supp. 311 (N.D. Miss. 1966).

27. See note 13 supra. It is not clear whether the defendant is bound by this earlier determination of competence, supra note 13 , or whether the subsequent proceedings are merely conducted under a reinstated rebuttable presumption of sanity, infra note 43.

28. See, e.g., Kienlen v. United States, 379 F.2d 20 (10th Cir. 1967); Splitt v. United States, 364 F.2d 594 (6th Cir. 1966), cert. denied, 385 U.S. 1019 (1967); State v. Alford, 98 Ariz. 124, 402 P.2d 551, cert. denied, 382 U.S. 1020 (1965); State v. Lewis, 11 N.C. App. 226, 181 S.E.2d 163 (1971). In re Williams, 165 F. Supp. 879 (D.D.C. 1958), seems to be the only case prior to Sieling which held that a defendant may be competent to stand trial without necessarily being competent to plead guilty. The court stated:

The issues involved in the plea of guilty and the consequences which attach to a plea require a greater degree of awareness than the competency to stand trial. The court may reasonably find, as it did in this case, that the latter competency may exist and still not feel justified in accepting a guilty plea on the defendant's behalf. Id. at 881 .

Although Williams is still considered good law, cf. L. Orfield, Criminal Procedure UNDER THE FEDERAL RULES $\$ 11: 26$ (1966), it must be noted that the case merely recognizes ground for the court, in its discretiou, to refuse to accept a guilty plea; the case does not hold, as did the Ninth Circuit in Sieling, that a guilty plea is invalid unless the defendant is expressly found competent to make the plea.

It should be noted that the "understand and assist" standard has been applied to the guilty plea only to determine a defendant's competency to plead guilty. After a defendant is found competent to plead guilty under this standard, the validity of the guilty plea in other respects nust then be determined. See notes 30-44 infra and acconpanying text.

29. See notes $45-48$ infra and accompanying text. 
has been found competent to stand trial does not seem to have been questioned.

\section{The General Requisites of a Valid Waiver or Guilty Plea}

The validity of a guilty plea or a waiver of constitutional rights is determined by a second body of standards and procedures which have developed independently of, and have been applied without reference to, those used to determine competence to stand trial. Although the constitutional requirements which govern the waiver of rights and those which test the validity of a guilty plea are themselves of distinot origin and differ in scope and detail, they impose a cominon prerequisite to the validity of any guilty plea or waiver-that it be the result of the defendant's free and intelligent choice. ${ }^{30}$ The courts

30. Compare Fay v. Noia, 372 U.S. 391, 439 (1963); Adams v. United States $e x$ rel. McCann, 317 U.S. 269, 275 (1942); Johnson v. Zerbst, 304 U.S. 458 (1938) (waiver), with Parker v. North Carolina, 397 U.S. 790, 801 (1970) (Brennan, J., dissenting); Von Moltke v. Gilkes, 332 U.S. 708, 728-29 (1948) (Frankfurter, J., concurring); Carter v. Illinois, 329 U.S. 173, 179 (1946); Annot., 25 L. Ed. 2d 1025 (1971) (guilty plea). For an analysis of the Johnson v. Zerbst standard that "[a] waiver is ordinarily an international relinquishinent of a known right or privilege," 304 U.S. at 464; see Tigar, Waiver of Constitutional Rights: Disquiet in the Citadel, 84 HARv. L. REv. 1, 8 (1970): “This standard stresses the consensual, 'free choice' character of waiver and its ultimate rehance upon the individual's freedom to forego benefits or safeguards through the uncoerced exercise of his rational facilities."

See also D. Newman, Conviction-The Determination of Guilt or InNoCENCE WITHOUT TRIAL 10 (1960) (criticism of the proposition that "voluntariness" is the sole constitutional criterion of the validity of a guilty plea). See also Shelton v. United States, 246 F.2d 571 (5th Cir. 1957).

The fact that a plea or waiver is "voluntarily and intelligently" tendered by a competent defendant does not mean that the court must accept it. Although a competent defendant may have had a common law right to plead guilty, see Arens, Due Process and the Rights of the Mentally Ill: The Strange Case of Fredrick Lynch, 13 CaTHourc U. AM. L. Rev. 3, 18 (1964), the Supreme Court has refused to recognize a constitutional right to plead guilty. See Lynch v. Overholser, 369 U.S. 705, 719 (1962) (where the trial court refused to accept the guilty plea of a defendant charged with a misdemeanor and, over his objection, entered a plea of not guilty by reason of insanity). Furthermore, in North Carolina v. Alford, 400 U.S. 25, 38 n.11 (1971), the Court stated:

Our holding does not mean that a trial judge must accept every constitutionally valid guilty plea merely because a defendant wishes to so plead. A criminal does not have an absolute right under the Constitution to have his guilty plea accepted by the court, although the States may by statute or otherwise confer such a right (citatious omitted).

See Comment, supra note 2, at 547.

Similarly, the Court also has rejected the contention that there exists a right to waive a jury trial:

A defendant's ouly constitutional right concerning the method of trial is to an impartial trial by jury. We find no constitutional impediment to conditioning a waiver of this right on the consent of the prosecuting attorney and the trial judge wheu, if either refuses to consent, the result is simply that the defeudant is subject to an impartial trial by jury - the very thing the Constitution guarantees him. Singer v. United States, 380 U.S. 24, 36 (1965). 
have expressed this requirement for the validity of both a guilty plea and waiver in similar language; in traditional terms, a guilty plea inust be "voluntarily and understandingly" made in order to be accepted. ${ }^{31}$ Similarly, under the standard imposed by the Supreme Court in Johnson v. Zerbst, ${ }^{32}$ a waiver must be "intentional" and the right must be "known." 33 Although occasionally a court will acknowledge in passing that it assumes the defendant to have some general "capacity" to inake the required intelligent choice, ${ }^{34}$ the courts have not inade an affirmative atteinpt to discern the presence of such a capacity, and the concept of what constitutes the capacity to waive a constitutional right or to plead guilty reinains unelaborated. The focus of the courts' inquiry instead has been upon the defendant's background, his conduct and the circumstances surrounding the tender of a waiver or plea; ${ }^{35}$ the standard of validity for a waiver or plea is defined essentially in terms of the absence of those factors which would render the choice

31. Kercheval v. United States, 274 U.S. 220,223 (1927). Brady v. United States, 397 U.S. 742, 755 (1970), approved as a standard for "voluntariness" the following passage from Judge Tuttle's dissent in Shelton v. United States, 242 F.2d 101, 115 (5th Cir. 1957):

[A] plea of guilty entered by one fully aware of the direct consequences, including the actual value of any commitments inade to him by the court, prosecutor, or his own counsel, inust stand unless induced by threats (or promises to discontinue improper harassment), misrepresentation (including unfulfilled or unfulfillable promises), or perhaps by promises that are by their nature improper as having no proper relationship to the prosecutor's business (e.g., bribes).

According to Hebering, supra note 2, at 157, "voluntariness" and "inteligence" actually comprise a single standard, "voluntariness" being the "operative concept." See also ABA Standards, Pleas of Guilty $\S \S 1.4-1.6$ (Approved Draft 1968).

32. 304 U.S. 458 (1938).

33. Id. at 464. The Supreme Court, in Fay v. Noia, 372 U.S. 391 (1963), applied this standard and emphasized the volitional element: "at all events we wish it clearly understood that the standard here put forth depends on the considered choice of the petitioner." Id. at 439 (emphasis added).

The standard was originally applied to the waiver of the right to counsel, Johnson v. Zerbst, 304 U.S. 458 (1938), but has been extended to the waiver of fifth amendment rights resulting from a pre-trial statement, Miranda v. Arizona, 384 U.S. 436 (1966), and, in Fay v. Noia, to the waiver of the right to appeal, 372 U.S. 391 (1963).

Certain rights, however, may be forfeited by actions not intended to operate as a waiver. For example, the right to be present at trial may be forfeited by disruptive behavior. Illinois v. Allen, 397 U.S. 337 (1970). See Tigar, supra note 30, at 911, 16-19.

34. See Von Moltke v. Gillies, 332 U.S. 708, 729 (1948) (Frankfurter, J., concurring); Carter v. Illinois, 329 U.S. 173, 179 (1946); Adams v. United States ex rel. McCann, 317 U.S. 269, 277 (1942); United States v. Plattner, 330 F.2d 271 (2d Cir. 1964). Plattner, a case holding that there is a constitutional right to conduct a pro se defense, seems to be unique in suggesting that an inquiry into the defendant's capacity to make a rational choice is a condition precedent to allowing his waiver of counsel and self-representation at trial. Id. at 276.

35. See, e.g., Johnson v. Zerbst, 304 U.S. 458, 464 (1938). 
involuntary-ignorance, mistake and unfair external pressure. ${ }^{36}$ Mental disability has been identified as one of these factors in dicta only, apparently because of the common law rule that an incompetent defendant cannot even be brought to trial and because the common law standard is regarded as governing questions of competence. ${ }^{37}$

Because of the importance of the right to counsel im preserving the free exercise of other constitutional rights in the criminal process, ${ }^{38}$ an affirmative duty is imposed on the court to determime in advance that a waiver of counsel is intelligently made and to indicate this clearly in the record..$^{39}$ Furthermore, because a guilty plea carries with it the waiver of several constitutional rights, this duty to assure that the waiver is intelligently made has been extended to require the court to conduct a colloquy with the defendant before accepting a guilty plea. ${ }^{40}$ While such an inquiry, insofar as it is meant to probe the defendant's intention and understanding, might properly be concerned with his actual state of mind, it usually consists imstead primarily of the determination that no external factors existed which could have unfairly influenced the guilty plea decision. Although the court is obliged to ask whether the defendant understands the charges and the consequences

36. Garrity v. New Jersey, 385 U.S. 493 (1967) (threats of discharge from employment made resulting incriminating statements inadmissible); Moore v. Michigan, 355 U.S. 155 (1957) (misleading statements by sheriff which led to a waiver of counsel vitiated waiver); Von Moltke v. Gillies, 332 U.S. 708 (1948) (erroneous legal advice and ignorance of rights vitiated waiver of counsel and guilty plea). See also Heberling, supra note 2, at 164-66; 42 CoLUM. L. REv. 271, 278 (1942).

37. See notes 14, 26-29 supra and accompanying text.

This is not to say that mental incompetence would not be a theoretically adequate ground for vacating a waiver, but rather that prior to Westbrook raising the issue of competence in connection with a waiver would apparently have been tantamount to questioning the validity of the entire proceeding.

However, the common law standard of competence to stand trial has not been applied in one area-pre-trial confession cases-where the "voluntary and intelligent" standard is used instead. Thus the requirement of an intelligent choice may play a more direct role in determining the measure of competence necessary for a valid waiver of the fifth amendment right against compulsory self-incrimination inherent in a confession than it does in evaluating the validity of other constitutional waivers. See Blackburn v. Alabama, 361 U.S. 199, 207 (1959); United States v. Silva, 418 F.2d 328, 330 (2d Cir. 1969). See also United States v. Bernett, No. 71-1465 (D.C. Cir. Jan. $10,1974)$.

38. See, e.g., Johnson v. Zerbst, 304 U.S. 458, 465 (1938) ("The purpose of the constitutional guaranty of a right to counsel is to protect an accused from conviction resulting from his own ignorance of his legal and constitutional rights . ..."); Powell v. Alabama, 287 U.S. 45, 68-69 (1932) ("The right to be heard would be, in many cases, of little avail if it did not comprehend the right to be heard by counsel.").

39. Carnley v. Cocliran, 369 U.S. 506 (1962); Johnson v. Zerbst, 304 U.S. 458 (1938); United States v. Plattner, 330 F.2d 271 (2d Cir. 1964).

40. Boykin v. Alabama, 395 U.S. 238 (1969). 
of pleading guilty, to explain them if he does not, and to inquire whether he has been subjected to threats or coercion, the court may accept his answers to these questions if they indicate an absence of coercion or undue influence; ${ }^{41}$ the defendant does not have to demonstrate his comprehension. ${ }^{42}$ Furthermore, in the ordinary case no inquiry into the defendant's mental capacity to make the plea is required-he is presumed sane. ${ }^{43}$ Commentators agree that this colloquy is neither designed for nor adequate for ascertaining inental incompetence. ${ }^{44}$

Thus prior to Westbrook the competence-to-stand-trial and the waiver/plea standards were employed in a complementary fashion: the "understand and assist" standard was used to establish the defendant's capacity to be tried and if this test were met, it was assumed that the defendant had the capacity to waive his constitutional rights and to enter a guilty plea; the voluntariness standard was used to validate the competent defendant's waivers and pleas im all other respects.

Westbrook $v$. Arizona AND the CASEs INTERPRETING IT

In Westbrook v. Arizona, ${ }^{45}$ the Supreme Court prescribed a con-

41. The standard of "voluntariness" adopted in Brady v. United States, 397 U.S. 742 (1970), also reflects this concern for external factors. See note 31 supra.

42. See, e.g., United States v. Goodman, 432 F.2d 75 (5th Cir. 1970). For an indication that the "presence and advice" of counsel tends to mitigate otherwise coercive factors, see Brady v. United States, 397 U.S. 742 (1970).

43. Splitt v. United States, 364 F.2d 594 (6th Cir. 1966), cert. denied, 385 U.S. 1019 (1967). Cf. Robinson v. Johnston, 50 F. Supp. 774 (N.D. Cal. 1943). But cf. Tex. Code CrIM. Proc. art. 26.13 (Vernon's 1966), under which no defendant's guilty plea may be accepted "... unless it plainly appears that he is sane ..." This statute has been interpreted to niean that a guilty plea is presumptive evidence of insanity, requiring a finding to the contrary before the plea nuay be accepted. See, e.g., Sanders v. State, 18 Tex. Crim. 372 (1885).

44. D. NeWMan, supra note 30 , at 24; Heberling, supra note 2, at 178 . It is suggested in ABA STANDARDs, supra note $31, \S 1.6$, Commentary, that adding a requirement that the court determine the factual basis of a plea before accepting it might help reduce the risk of an incoinpetent's pleading guilty.

45. 384 U.S. 150 (1966). The Court's brief per curiam opinion reads as follows:

The notion for leave to proceed in forma pauperis and the petition for a writ of certiorari are granted. Althougli petitioner received a hearing on the issue of his competence to stand trial, there appears to have been no hearing or inquiry into the issue of his conpetence to waive his constitutional right to the assistance of counsel and proceed, as he did, to conduct his own defense. "The constitutional right of an accused to be represented by counsel invokes, of itself, the protection of a trial court, in which the accused-whose life or liberty is at stake-is without counsel. This protecting duty imposes the serious and weighty responsibility upon the trial judge of determining whether there is an intelligent and competent waiver by the accused." Johnson v. Zerbst, 304 U.S. 458, 465; Carnley v. Cochran, 369 U.S. 506.

Froin an independent examination of the record, we conclude that the question whether this "protecting duty" was fulfilled sliould be re-examined in light of our decision this Term in Pate v. Robinson, 383 U.S. 375 . Accordingly, the judgment of the Supreine Court of Arizona is vacated and the case is remanded to that court for proceedings not inconsistent herewith. 
stitutional exception to the unwritten but general rule that finding of competence to stand trial established competence for all purposes of a criminal proceeding. The Court held that a finding of a defendant's competence to stand trial does not establish his competence to waive the right to counsel and to represent himself. The defendant in Westbrook, charged with murdering an attorney, waived counsel and unsuccessfully defended himself. On appeal, the Supreme Court of Arizona $^{46}$ rejected his argument that the determination of his mental competence to assist in his own defense under Arizona's Rule 250, governing competence to stand trial, did not amount to a finding that he was mentally competent to conduct his own defense, and that his waiver of counsel was therefore invalid. In a very brief opinion, the Umited States Supreme Court reversed and remanded, stating:

Although petitioner received a hearing on the issue of his competence to stand trial, there appears to have been no hearing or inquiry into the issue of his competence to waive his constitutional right to the assistance of counsel and proceed, as he did, to conduct his own defense. ${ }^{47}$

Although Johnson v. Zerbst was cited by the Court for the proposition that it is the trial court's responsibility to ascertain whether a valid waiver of counsel has been made, the Court did not indicate what kind of "hearing or inquiry" should have been conducted, nor did it explain how such an inquiry would differ from the hearing under Rule 250. Whether the "protective duty" imposed by Johnson v. Zerbst had been fulfilled was to be determined on remand in light of Pate v. Robinson $^{48}$ a then-recent competence-to-stand-trial case which imposed a duty on the court to conduct a hearing on its own initiative when facts come to its attention indicating that the defendant might be incompetent to stand trial.

Prior to Sieling, the Westbrook decision had gone largely unnoticed. The cases applying it, most of which concern the validity of a particular defendant's waiver of counsel, ${ }^{49}$ have drawn different conclusions as to what factor or factors present in Westbrook necessitated

46. State v. Westbrook, 99 Ariz. 30, 406 P.2d 388 (1965).

47. 384 U.S. at 150.

48. 383 U.S. 375 (1966).

49. People v. Dumas, 51 Misc. $2 d$ 929, 274 N.Y.S.2d 764 (Sup. Ct. 1966), appears to be the only case in addition to Sieling which recommends an extension of the Westbrook rationale to other constitutional rights. It was suggested in Dumas that Westbrook might require the determination of the defendant's coinpetence to make the waiver of rights involved in a confession before a confession could be admitted into evidence. At issue would be the defondant's ability to understand the Miranda warning. 
the additional inquiry as to the defendant's competence to waive counsel-the decision to forego the assistance of counsel (that is, the waiver itself), the defendant's subsequent self-representation at trial, or both. $^{50}$ In State v. Martin, ${ }^{51}$ the Arizona Supreme Court focused on the first element, the defendant's coinpetence to decide to forego the assistance of counsel, stating that neither the extent of the defendant's legal skills nor the ultimate wisdom of his decision was relevant to the waiver's validity. ${ }^{52}$ However, the Arizona court has not shown any inclination to broaden this reading of Westbrook to require a finding of coinpetence, in addition to that necessary to stand trial, for the waiver of other constitutional rights or for the entry of a guilty plea. ${ }^{53}$ In contrast to the focus in Martin, two cases-State v. Kolocotronis ${ }^{54}$ and Virgin Islands $v$. Niles ${ }^{5}$ _ - have placed emphasis on the second element, the level of competence necessary for self-representation at trial, rather than on that required for the making of the waiver. ${ }^{58}$ In Kolocotronis, the Supreme Court of Washington held that due process is violated if a court allows a defendant to represent himself who does not have the competence to do so. ${ }^{57}$ This narrow view of Westbrook seems to preclude

50. The difference may be significant since one who waives counsel and thereafter pleads guilty does not need to conduct any defense.

51. 102 Ariz. 142, 426 P.2d 639 (1967).

52. Id. at $146,426 \mathrm{P} .2 \mathrm{~d}$ at 643.

53. Factual situations in several subsequent cases have provided the opportunity to apply Westbrook to the guilty plea. However, in State v. Davis, 106 Ariz. 598, 480 P.2d 354 (1971) (presentence report raises doubt as to competence at time of plea), and State v. Rojas, 103 Ariz. 431, 443 P.2d 427 (1968) (failure to hold a competency hearing invalidates a gnilty plea), the Supreme Court of Arizona instead prescribed the Rule $250 /$ common law standard to determine the competence of guilty pleas. In State v. Makal, 106 Ariz. 591, 480 P.2d 347, cert. denied, 404 U.S. 838 (1971), the court faced a situation identical to that in Sieling but did not apply the Westbrook rationale. There is no indication in any of these cases, however, that the defendant argued for an extension of Westbrook.

54. 73 Wash. 2d 92, 436 P.2d 774 (1968).

55. 295 F. Supp. 266 (D.V.I. 1969).

56. In the Niles case, after finding the defendant competent to stand trial, the court stated: "As for defendant's competency to waive counsel, the court is of the opinion that one who may be suffering from paranoid delusions should not be entrusted with the sole conduct of his defense." 295 F. Supp. at 266.

Furthernore, the court in Kolocotronis stated: "[Westbrook] holds unequivocally, that an adjudication by the trial court that an accused is capable of going to trial and aiding his counsel, is not a determination of his competency to act as his own counsel." 73 Wash. $2 \mathrm{~d}$ at 101,436 P.2d at 781. Although stating at one point that the court must assess both the defendant's competence to waive and his competence to defend, the Kolocotronis court's further discussion indicates that the validity of the waiver would ultimately be determined by the capacity for self-representation. Id. at 101-02, 436 P.2d at 781 .

57. 73 Wash. $2 d$ at 99,436 P.2d at 779-80. 
its application to the waiver of rights other than the right to counsel since it focuses on an issue associated only with the right to counsel-the capability for self-representation.

The reasoning inherent in this second approach was extended to its logical conclusion in Splitt v. United States ${ }^{58}$ when the Sixth Circuit expressly lield that Westbrook applies only to cases in which the defendant represents himself at trial. In Splitt, the defendant waived counsel and pleaded guilty after a court-ordered psychiatric examination had found him fit to proceed. After conducting a careful inquiry into Splitt's understanding of the charges and the consequences of pleading guilty, the trial court accepted his plea. ${ }^{59}$ The court of appeals held that the guilty plea colloquy established the validity of the plea, noting that, in view of the evidence against him, Splitt's decision was an "intelligent one." B0 Brushing aside the defendant's claim that Westbrook should apply, the court distinguished Westbrook on the grounds that, although Splitt had waived his right to counsel, he had not atteinpted to defend himself. ${ }^{61}$ Splitt reflects the general consensus of the pre-Sieling cases that the specific coinpetence required in Westbrook is that of self-representation-a competence peculiar to the waiver of counsel; in addition, Splitt conflicts directly with Sieling in liolding not only that Westbrook cannot apply to invalidate a guilty plea, but also that a guilty plea colloquy can validate the plea of a defendant who has been found competent to stand trial. ${ }^{62}$

\section{Sieling v. Eyman: THe CourT's LoGrc}

In Sieling, the Ninth Circuit, accepting the contention that the Westbrook holding is sufficiently broad to invalidate a guilty plea even where there has been no waiver of counsel, specifically held that the finding of competence to stand trial under the Rule 250 (and common law) standard was insufficient to establish Sieling's competence to plead guilty. The court's opinion is ultimately syllogistic in character. Its major premise is an expansive reading of the intended scope of the Westbrook decision; although the court never specifically so states, it is clear that it perceived the Westbrook rule to require a finding of competence not only for the conduct of one's own defense at trial, but also for the waiver of the assistance of counsel, and thus for the waiver

58. 364 F.2d 594 (6th Cir. 1966), cert. denied, 385 U.S. 1019 (1967).

59. Id. at 595-97. Neither the trial court's original opinion nor the lower court's dismissal of his motion to vacate the sentence was reported.

60. Id. at 598.

61. Id.

62. See text accompanying notes 67-68 infra. 
of all fundamental constitutional rights. ${ }^{63}$ The court's minor premise, drawn from statements in Boykin v. Alabama, ${ }^{64}$ is that the plea of guilty as a consent to judgment has all the consequences of a conviction and involves the waiver of several important constitutional rights - the fifth amendment right against compulsory self-incrimination and the sixth amendment rights to a jury trial and to the confrontation of witnesses. ${ }^{65}$ Under the broad major premise, the court concluded that, since a finding of the defendant's competence to stand trial was held insufficient for the waiver of a constitutional right in Westbrook, such a finding cannot serve as an adequate evaluation of a defendant's competence to make the waiver of constitutional rights which, according to the Boykin minor premise, is inherent in a guilty plea. ${ }^{66}$

The guilty plea colloquy is, in the Sieling court's view, an equally inadequate test of the validity of such a waiver because, as the court notes, the colloquy is directed toward external circumstances and is conducted under the presumption of sanity. ${ }^{67}$ Indeed, the court seems to read Westbrook to imply that, once there is a question as to a defendant's competence to act in his own behalf, the usual inquiry accoinpanying the waiver of other constitutional rights will likewise be insufficient. ${ }^{88}$

Westbrook was further interpreted by the court as holding that the traditional determination of a defendant's competence to stand trial is insufficient to determine competence to plead guilty because that deterinination does not measure the defendant's capacity "by a high enough standard." Although the court spoke of "level" and "degree," it proceeded to adopt a standard which seems to contemplate the assessment

63. Passages in Sieling coinmenting on the Westbrook opinion indicate that the Sieling court interpreted Westbrook in this broad fashion:

The Court [in Westbrook] held that a trial court finding under Arizona Criminal Rule 250, that the defendant was competent to assist counsel in his defense, did not suffice as a finding that he was also competent to waive such a fundamental constitutional right as the right to the assistance of counsel. 478 F.2d at 213 (emphasis added).

We think Westbrook inakes it plain that, where a defendant's competency has been put in issue, the trial court must look further than to the usual "objective" criteria in determinimg the adequacy of a constitutional waiver. Id. at 214 (emphasis added).

At no point in the opiniou does the court discuss the possibility that Westbrook might be limited to self-representation or even to foregoing the assistance of counsel. See notes 50-58 supra and accompanying text.

64. 395 U.S. 238, 242-44 (1969).

65. See note 2 supra.

66. 478 F.2d at 215.

67. Id. at 214. See notes 39-44 supra and accompanying text.

68. Id. See note 63 supra (second passage quoted).

69. Id. 
of an ability different in kind from that measured by the "understand and assist" test of competence to stand trial-namely, the capacity to make a decision. Thus the Sieling court stated:

While the [Westbrook] Court did not suggest a standard, it is reasonable to conclude from the Court's language that the degree of competency required to waive a constitutional right is that degree which enables [the defendant] to make decisions of very serious import. ${ }^{70}$

For competence to plead guilty, the Sieling court approved the standard suggested by Judge Hufstedler in her dissent in Schoeller v. Dunbar:

A defendant is not competent to plead guilty if a mental illness has substantially impaired his ability to make a reasoned choice among the alternatives presented to him and to understand the nature of the consequences of his plea. ${ }^{71}$

The court considered this standard appropriate because "it requires a court to assess a defendant's competency with specific reference to the gravity of the decisions with which the defendant is faced."72 Conceding that a retroactive determination of competence is impossible where a defendant was not examined at the time of a much earlier original trial, the court concluded that, in view of the short interval between Sieling's competency hearing and his guilty plea, the psychiatric reports and testimony at that earlier hearing might provide a basis for a finding of his coinpetence to plead guilty. ${ }^{73}$ This seems to indicate that the court did not find it essential to the validity of a guilty plea that the Sieling test be admimistered and that the finding be made at the time the guilty plea is entered; instead in future cases the issue of the defendant's coinpetence to plead guilty could be determined along with the defendant's competence to stand trial at a pretrial hearing.

70. Id. at 214-15. While this statement might seem to refer merely to a level of cognitive functioning necessary for decision-making rather than to the ability to decide, the standard adopted in Sieling for the guilty plea clearly focuses on this latter volitional element. See text accompanying note 71 infra.

71. 423 F.2d 1183, 1194 (9th Cir. 1970). Judge Hufstedler's suggestion of a new competency standard for the guilty plea was merely tangential to the issue of the case, the proper scope of review in a federal habeas corpus proceeding challenging a previous finding of competence. It is siguificant for the understanding of the "volitional" standdard suggested by Judge Hufstedler that the defendant in Schoeller was an unusually intelligent and articulate person whose lucidity was unimpaired by the mental illness he allegedly suffered. 423 F.2d at 1184-85. Because of the defendant's intelligence, he probably possessed the cognitive component necessary to make a rational choice, and as a result, had an evidentiary liearing been ordered, the issue of the defendant's competence to plead guilty would lrave turned directly on the volitional element.

72. 478 F.2d at 215 (footnotes omitted).

73. Id. at $215-16$. 
Sieling v. Eyman: RELIANCE ON WESTBROOK

In order to reach the Sieling court's conclusion that a finding of competence to stand trial is not sufficient to establish competence to plead guilty, it is necessary to establish that there are at least two standards of coinpetence and that satisfying the competence-to-stand-trial standard does not necessarily result in satisfying the standard for competence to enter a guilty plea.

Although the Sieling court relied on Westbrook for both of these propositions, Westbrook is inadequate support for the first and very weak support for the second. Westbrook did not state that there was a different standard or degree of coinpetence even in the limited right-to-counsel situation of that case, and the existence of such a separate standard is not a necessary implication of Westbrook.

The Sieling court reasoned that the additional hearing or imquiry required in Westbrook would only be necessary because the first, which established competence to stand trial, was "imadequate" to ineasure competence needed to waive a constitutional right. ${ }^{74}$ Unfortunately, the Westbrook Court did not explain exactly how the second inquiry should differ, if at all, from the first, but instead, on the basis of its "independent examination of the record," the Supreme Court simply ordered the state supreme court to determine whether the Johnson $v$. Zerbst "protective duty" to assure that the waiver of the right to counsel be valid had been fulfilled in view of the Pate v. Robinson rule that the trial court inust conduct a hearing sua sponte, if facts indicating incompetence come to its attention. ${ }^{75}$ If Westbrook, indeed, meant to propose a new standard, it is difficult to see how a trial court might have fulfilled its duty to ascertain the validity of a waiver without know$\mathrm{mg}$ the standard in advance, and it is similarly difficult to understand how the Arizona Supreme Court on remand was to review the trial court's actions without knowledge of the standard.

It is possible that the Supreme Court in Westbrook would have been satisfied with an additional finding of competence made at the time of the waiver without requiring a different type or degree of competence. $^{70}$ A reason for interpreting Westbrook as imposing such a lesser requirement can be found in the facts that mental illness is fre-

74. Id. at 214.

75. See note 45 supra and text accompanying note 48 supra.

76. The Sieling court apparently did not consider the time of the waiver or plea critical; instead, it would permit a determination of the defendant's competence to plead or waive im an earlier general competency hearing. See note 73 supra and accoinpanying text. 
quently episodic ${ }^{77}$ and that the defendant's mental condition may well change in the often lengthy period of time between the competency hearing, usually held at the time of arraignment, ${ }^{78}$ and the trial itself. ${ }^{70}$ Since the waiver of counsel may be an unwise decision for even the normal defendant, ${ }^{80}$ and one which a disturbed person might be more likely to make, and smce the imcompetent defendant has an even greater need for counsel's assistance than does the normal defendant, ${ }^{81}$ the Westbrook Court may have thought it a necessary precaution that a court which has found reason to inquire into a defendant's competence at an earher stage of the proceedings should also ascertain whether that defendant is still competent at the time he waives counsel.

Westbrook provides support for the second proposition-that meeting the competence-to-stand-trial standard does not necessarily result in satisfying the competence-to-plead-guilty standard-only if Westbrook can be interpreted as requiring a different type or degree of competence (from that necessary to stand trial) for the waiver of other constitutional rights in addition to the right to counsel. However, it is impossible to view Westbrook as having established any rule applicable to all fundamental constitutional rights, and thus to the entry of a guilty plea, without considerably distorting its language. The only references to constitutional rights in Westbrook are to the right to be represented by counsel; the unqualified phrase "a constitutional right" does not appear in the opinion. ${ }^{82}$ In addition, the waiver of the right to counsel in Westbrook cannot be treated as the equivalent of the

77. For a description of the episodic nature of mental illness and the lucid intervals which are especially characteristic of manic-depressive psychosis, see WEIHOFEN 232-34.

The issue of episodic or intermittent incompetence has been raised in cases involving the use of narcotic drugs and alcohol. See, e.g., United States v. Goodman, 432 F.2d 75 (5th Cir. 1970); Logner v. North Carolina, 260 F. Supp. 970 (M.D.N.C. 1966), affd, 392 F.2d 222 (4th Cir.), cert. denied, 393 U.S. 857 (1968); State v. McFall, 5 Ariz. App. 539, 428 P.2d 1013 (1967). See also Heberling, supra note 2, at 17879.

78. Note, Incompetency to Stand Trial, supra note 13, at 454.

79. See, e.g., Robey, supra note 23 , at $619-20$, where it is suggested that some prediction of future stability should be included in the psychiatrist's report to counteract the possibility that a change in a defendant's mental condition nay escape notice.

80. See, e.g., State v. Beasley, 184 Neb. 649, 651, 171 N.W.2d 177, 178 (1969) (waiver of counsel described as "a gross error in judgment").

81. Cf. Cohen, The Function of the Attorney and the Commitment of the Mentally IIl, 44 Tex. L. Rev. 424, 458 (1966), where it is suggested that in view of the helplessness of the incompetent defendaut and his inability to judge his attorney's actions, the attorney be required to file reports to the court. See generally Chernoff \& Schaffer, supra note 16.

82. See notes 45 and 63 supra and accompanying text. 
waiver of other rights without regarding the Supreme Court's reference to the defendant's "competence . . . to conduct his own defense" as mere surplusage. The Sieling court took no cognizance of the cases interpreting Westbrook which focused on the competence to conduct one's own defense. ${ }^{84}$

Insofar as Westbrook is susceptible to conflicting interpretations as to its support for each of the two propositions-that there are at least two standards of competence and that satisfying the competence to stand trial standard does not necessarily result in satisfying the standard for competence to enter a guilty plea-the result in Sieling cannot be justified on the basis of Westbrook alone. ${ }^{85}$

83. 384 U.S. at 150.

84. See notes 54-62 supra and accompanying text.

85. The Sieling court's heavy rekance on Westbrook perhaps also accounts for its failure to give any consideration to the significant differences among the various rights encompassed by any single standard for a competent waiver-first, with respect to the interests those rights protect; second, with respect to the benefits to be gained from their waiver and whether these benefits can be denied a defendant without jeopardizing the fairness of the proceedings; and third, with respect to the different situations in which the rights appear in order to determine whether the demands of the situation upon the defendant's competence increase the likelihood that his waiver will be involuntary.

For example, in the area of mental competency, the right to counsel might be distinguished from all others in regard to the particular interests to be protected: it is defendant's counsel in the first instance who is expected to raise the issue of competence at whatever stage of the proceedings it might become necessary. Cf. Seidner v. United States, 260 F.2d 732, 733 n.1 (D.C. Cir. 1958) ("It would be anomalous indeed to require a possibly incompetent person to present the issue of his own incompetency while he repeatedly denies that he is now or ever has been mentally incompetent."); Dooling v. Overholser, 243 F.2d 825 (D.C. Cir. 1957) (no waiver of counsel permitted in a commitment hearing). On the other hand, the benefits to be gamed from the waiver of counsel and particularly from a pro se defense seem minimal at best. See note 80 supra and accompanying text. Thus it might be argued that an especially high standard of competence be required for the waiver of counsel by a defendant who has a history of mental illness.

In contrast, testifying in one's own behalf-which is probably essential for an effective defense in the nornal case-entails at least a pro tanto waiver of the fifth amendment privilege against self-imcrimination for the purposes of cross-examination, Brown v. United States, 356 U.S. 148 (1958); Fitzpatrick v. United States, 178 U.S. $304,315(1900)$. In order to permit as many defendants as possible to use this means of defense, the competence to make the automatic waiver which accompamies it might be judged by a less rigorous standard.

And yet it is not clear that identical considerations would apply to the waiver of the fifth amendment in the various situations in which it is found-e.g., the confession, the guilty plea and testimony at trial. For instance, it might be argued that a higher standard of competence to make a rational choice is necessary in the inherently coercive custodial interrogation situation. Cf. Miranda v. Arizona, 384 U.S. 436, 455,457 (1966). 


\section{Should SeParate StandaRid Govern Competence To Stand TRIal aND To Plead Guilty?}

The competence standard set forth in Sieling seems particularly appropriate for both the waiver of constitutional rights and the entry of a guilty plea because it focuses on the ability to make decisions. ${ }^{80}$ In the form suggested by Judge Hufstedler, the standard consists of both cognitive and volitional elenents-the ability to make freely a "reasoned choice," and the ability to understand its consequences unimpaired by mental disability. The appropriateness of this standard results from the fact that it reflects the traditional requisite of any vahid guilty plea on constitutional waiver - that it result from a voluntary and intelligent choice. Since mental disability may be seen as a factor which, like coercion and ignorance, renders the defendant's action "involuntary," the Sieling opinion can be seen as recognizing a standard for competence to plead guilty which is inherent in the requirements for waiver and for a guilty plea. ${ }^{87}$

On the other hand, the "understand and assist" test of competence to stand trial rejected by the Nimth Circuit in Sieling as an invalid test of a guilty plea does not on its face purport to measure the ability to make decisions. ${ }^{88}$ Instead, a defendant may proceed to trial if he has adequate recall, present lucidity, and some reasoning ability ${ }^{80}$ Thus, the court could have quite properly ruled as an abstract proposition that the Rule 250 test did not measure Sieling's ability to make a "reasoned clroice."

However, if the rationale for a decisional standard in a situation in which a decision is required is accepted, it would seem that it is the standard of competence to stand trial generally, rather than that necessary for entry of a guilty plea, which should bo reexamined. ${ }^{.0}$ In the first place, for the normal defendant, the decision to go to trial rather than enter a guilty plea is itself a critical one in the present criminal justice system: one who exercises his right to go to trial and is found

86. See notes 30-36 supra and accompanying text.

87. By merely restating the existing standard of voluntarmess $i m$ terms of another vitiating factor-mental incompetence-the Sieling decision can be viewed as a clarification of existing law; thus, rather than relying exclusively on Westbrook, the Sieling court could have found additional support for its standard in the law surrounding the waiver of constitutional rights.

88. See note 16 supra and notes 24-25 supra and accompanying text.

89. See, e.g., Dusky v. United States, 362 U.S. 402 (1959) (quoted in part in note 17 supra); Schoeller v. Dunbar, 423 F.2d 1183 (9th Cir.), cert. denied, 400 U.S. 834 (1970); Powell v. Umited States, 149 F. Supp. 356, 361 (M.D. Ala. 1957); A. MATTHEws, supra note 13, at 19.

90. See note 16 supra and notes $24-25$ supra and accompanying text. 
guilty may well be penalized by a stiffer sentence in a system which encourages disposition of most criminal cases by plea bargain ${ }^{91}$ and in which the prosecution is free to charge the defendant with multiple counts for the same crime in order to strengthen its bargaining position. ${ }^{92}$ In terms of pure mental ability, it would seem that the same level of competence would be necessary for either pleading guilty or not guilty. Under Sieling, only competence to make the former plea is scrutinized. Second, the defendant at trial faces a number of decisions which, though perhaps not as momentous as the decision of whether to plead guilty, are at least as complex: he must decide, with the assistance of his counsel, such things as whether to plead insanity, tenporary insanity, alibi, or some other affirmative defense, and whether to take the stand. ${ }^{93}$ Furthermore, the defendant at trial faces more than decisions. For example, the demands of testifying and the rigors of submitting to cross examination both heavily tax the abilities of a marginally competent defendant. ${ }^{94}$

Thus, it is likely that an accurate finding of competence to stand trial should require a level of competence equivalent to that required to plead guilty. ${ }^{95}$ Furthermore, if the present standard permits or re-

91. See Note, The Unconstitutionality of Plea Bargaining, 83 HARv. L. REv. 1387 (1970). In Heberling, supra note 2, at 137-39, it is even suggested that plea bargaining accoinparied by reduced sentences is a universal and necessary component of the present system of criminal justice. Furthermore, the Supreme Court has recently given express recognition to the role of plea bargaining in the criminal process; see, e.g., Santobello v. New York, 404 U.S. 257 (1971), holding that a defendant has a due process right to "specific performance" of his plea bargain. For a comprehensive discussion of plea bargaining and the role it plays in the criminal process, see D. NEwMAN, supra note 30 .

92. See, e.g., Heberling, supra note 2, at 148. Sieling itself may represent an example of this phenomenon, see text accompanying note 3 supra.

93. See Robey, supra note 23, at 619; Note, Incompetency to Stand Trial, supra note 13, at 458. See also Comment, Criminal Waiver: The Requirements of Personal Participation, Competence and Legitimate State Interest, 54 CaLIF. L. REv. 1262, 1267-68 (1966).

94. See Robey, supra note 23, at 619:

[T] the circumstances of the case make it necessary, [the defendant] must show the capacity to testify in his own defense. Generally speaking, if such testimony is required, the level of competency should be higher.

The inability to testify in one's own behalf is one of the factors which traditionally is supposed to render the trial of an incompetent unfair; there is always some possibility that, were the defendant coinpetent, he would be able to bring forth the facts needed to prove his innocence.

95. However, some commentators have assumed that a higher degree of competence is required for competence to stand trial. See Chernoff \& Schaffer, supra note 16, at 522 (discussion of the ethical dilemma presented to counsel when the defendant is capable of entering a voluntary and intelligent plea but it is doubtful that he can withstand the rigors of trial); cf. Comment, supra note 93, at 1269-72 (criticizing the re- 
quires a defendant to go to trial without the capacity to make decisions, then, whether or not this capacity is required for the entry of a guilty plea, the defendant is not assured the "fundamental fairness" which the law regarding competence seeks to provide. $^{96}$

\section{Practical Effects of the Sieling Decision}

The court in Sieling may be criticized for failing to consider the practical effects of its decision. Even assuming the correctness of the court's conclusion that a higher level or a different type of competence should be required to plead guilty than that required by the competenceto-stand-trial test and that Westbrook requires this second standard, it is possible that the establishment of a different standard such as that set forth by the Sieling court will have no practical effect whatsoever. Certainly the competency hearing can be modified to include an imquiry into the defendant's competence to waive constitutional rights. But the differences between the levels or types of competence in question may not be scientifically ascertainable, and, even if they were, under the prevailing practice they might well be merged in a single determination by the psychiatrists that the defendant is or is not mentally iill. $^{97}$

If Sieling's dual standard does have any practical effects, one may be to create a class of semi-competent defendants who are not protected froin prosecution because they have been found competent to stand trial, but who are denied the lemency of the plea bargaining process because they are not competent to plead guilty. ${ }^{98}$ Further-

quirement of a personal waiver (Fay v. Noia, 372 U.S. 391 (1963) for various rights at trial in view of the average defendant's inability to understand what is at issue, and suggesting that pretrial waivers, especially those associated with the guilty plea, are much less susceptible to this criticism). Id. at 1271 n.70. See also Uelmen, Competency to Stand Trial, in 1 Crmminal Defense Techniques $\$ 17.02[2]$ (R. Cipes ed. 1973).

96. See Wentofen 429; A. Matthews, supra note 13, at 19.

97. See notes 22-23 supra and accounpanying text.

98. There is evidence that charges are commonly reduced for defendants of low mentality. D. NewMaN, supra note 30, at 121-22. However, the "semi-competent" defendant would have to rely completely on this prosecutorial or judicial discretion, in contrast to the competent defendant, who is able to plea bargain-he can offer to plead guilty in return for a reduced charge or sentence. As noted previously, one commentator has suggested that plea bargaining accompanied by reduced sentences is a universal and necessary component of the present system of criminal justice. Heberling, supra note 2, at 137-39. It is ironic that, in attempting to protect a defendant's rights by denying him the chance to plead guilty, the court may in fact expose him to the same arbitrariness and discrimination against which constitutional rights are supposed to protect.

This unfortunate position scems to be shared under existing law by those whose guilty pleas unay be refused by the court in its discretion on the ground that they 
more, it would seem to follow that because a court applying the Sieling standard to ascertain competence to plead guilty is thus determining the defendant's competence to waive other constitutional rights inherent in a plea of guilty, these semi-competent defendants who are competent to stand trial but not competent to plead guilty will also be found ineligible to waive other constitutional rights.99

The purpose of the Sieling test is, of course, to protect the defendant from the loss of his rights through an involuntary waiver. It is true that under the Johnson v. Zerbst line of cases certain rigid procedures and standards of behavior are imposed upon the court and the prosecution to protect against the state's power and the defendant's ignorance, ${ }^{100}$ and, consequently, it might seem that mental imcompetence should be treated like any other factor which subverts a defendant's free choice and understanding. However, those external procedures and standards of behavior are set up at the prosecution's expense and serve to protect the defendant. Thus, it is far from clear that the same rigidity is desirable for determining competence to plead guilty since it may operate to hinder the defendant, rather than protect him, and, by disallowing his waiver if he is judged incompetent, may force him to exercise his rights and thereby cut off his ability to plead guilty or waive other trial rights. ${ }^{101}$

have a valid defense to the charges. Cf. Lynch v. Overholser, 369 U.S. 705,732 (1962) (Clark, J., dissenting). Under Sieling's per se rule, the court does not have discretion to accept or reject a guilty plea.

99. For example, Sieling gives no indication how the court will resolve the quandary of the defendant who is incompetent to waive his fifth amendment right against selfincrimination inherent in the guilty plea and who, upon being sent to trial, is by the same measure incompetent to testify in his defense because of the fifth amendment waiver his testimony involves. The decision not to testify may likewise involve the waiver of a constitutional right. See United States v. McCord, 420 F.2d 255, 257 (D.C. Cir. 1969). Contra, Sims v. Lane, 411 F.2d 661, 664-65 (7th Cir.), cert. denied, 396 U.S. 943 (1969) (inaking the point that in the federal courts the privilege of an accused to testify is merely statutory). This waiver must be made personally by the defendant. Poe v. United States, 233 F. Supp. 173, 176 (D.D.C. 1964), aff'd, 352 F.2d 639 (D.C. Cir. 1965).

100. See, e.g., Boykin v. Alabama, 395 U.S. 238 (1969) (requiring a plea colloquy); Miranda v. Arizona, 384 U.S. 436 (1966) (requiring a "warning" of the waiver of rights involved in a defendant's statement in a custodial interrogation setting).

101. In Adams v. United States ex rel. McCann, 317 U.S. 269 (1942), the Supreme Court recognized that a determination of competence to waive a constitutional right by means of a mechanical test insensitive to individual differences is "to imprison a man in his privileges," and to deprive him of his right to act in his own best interests. $I d$. at 280 . In other cases, where petitioners argued that a competent defendant should have an unconditional right to plead guilty and to waive constitutional rights, the Court has found this reasoning unpersuasive. See Singer v. United States, 380 U.S. 24 (1965); Lynch v. Overholser, 369 U.S. 705 (1962), discussed in note 30 supra.

A court, however, using the "reasoned choice" standard set forth in Sieling in a 
The Sieling decision, unless given only prospective effect, ${ }^{102}$ will have a second practical result; it will create a new infirmity in the convictions of many persons who, like Gilbert Sieling, pleaded guilty after being found competent to stand trial. ${ }^{103}$ Before Sieling, opportunity

flexible manner could avoid this problem by simply refusing to enforce a particular waiver against a defendant when it appears that mental disability has played a substantial role in the decision to make the waiver. For instance, in United States v. Silva, 418 F.2d 328 (2d Cir. 1969), the court allowed the withdrawal of a written waiver of rights and a confession because the defendant, under the influence of narcotics, had been incompetent at the time of the waiver. Such a flexible use of the standard would differ greatly from a single pre-trial determination of the defendant's eligibility to make all future waivers, and would eliminate this practical problem presented by the Sieling decision.

102. The decision to apply a new constitutional rule only prospectively is not necessarily itself a constitutional one, Linkletter v. Walker, 381 U.S. 618, 629 (1965), but is rather a policy decision balancing a variety of considerations: the purpose of the rule, i.e., whether it is essential to the fairness and accuracy of the proceedings, id at 639; Roberts v. Russell, 392 U.S. 293, 294-95 (1968), or merely intended to have a deterrent effect on future police behavior, Linkletter v. Walker, supra at 636-37; the extent of reliance by the courts and law enforcement authorities on the prior law, Tehan v. United States ex rel. Shott, 382 U.S. 406, 416-17 (1966), or whether instead the new rule was clearly foreshadowed by preceding developinents, Johnson v. New Jersey, 384 U.S. 719, 734 (1966); the effect of retroactivity ou the administration of justice, Tehan v. Umited States ex rel. Shott, supra at 418; and whether the defendant has had alternative means of vindicating his rights, Johnson v. New Jersey, 384 U.S. 719, 730 (1966). In Robinson v. Neil, 409 U.S. 505, 508-09 (1973), a case giving retroactive effect to a double-jeopardy rule, the Court held that this balancing approach is not necessarily applicable to what it called "non-procedural" rules. Compare Gosa v. Mayden, 413 U.S. 665 (1973).

If the balancing approach is used to determine whether to limit the Sieling standard to prospective effect, the Ninth Circuit will face conflicting equities. On the one hand, the reliance of courts and prosecutors on the applicability of the competency to stand trial standard to guilty pleas is substantial, and, even if it could be argued that the Sieling standard was inherent in the law of the waiver or that Westbrook provided a compelling basis for the Sieling decision, Sieling was not adequately foreshadowed by either of these facts. In addition, the effect on the system of justice may also be substantial; many convicted defendants may seek habeas corpus relief on the basis of Sieling.

On the other hand, under common law the conviction of an inconupetent defendant is absolutely void, primarily because of the unfaimess and unreliability of such a conviction. It seems, therefore, that full retroactive effect should be given under the Sieling standard to grant habeas corpus relief to a defendant who was in fact lacking the ability to make a rational choice. The nore difficult question is whether the full reach of the Sieling rule should be allowed retroactive effect to afford defendants in cases similar to Gilbert Sieling's a review of their convictions merely because a competency hearing has put their competence at issue without resolving the question of their competence to plead guilty. In such cases perhaps a "harmless errox" threshold could be used to require the defendant to make some showing of possible prejudice. See Johnson, The Supreme Court of California 1967-68-Foreword: Retroactivity in Retrospect, 56 CALIF. L. Rev. 1612, 1631-32 (1968).

103. Although statistics do not seem to be available which indicate accurately the number or percentage of defendants who have both beeu determined competent to stand 
for collateral attack of the validity of convictions in competence cases seems to have been limited to cases in which the court failed to hold a hearing when reasons for doubting competence were before it, ${ }^{104}$ or to cases where the defendant could actually prove he had been incompetent at the time of the trial or the guilty plea. ${ }^{105} \mathrm{~A}$ judicial finding of

trial and have pleaded guilty, the following figures may be helpful in assessing the impact of Sieling on the criminal justice system: (1) According to Bacon, Incompetency to Stand Trial: Commitment to an Inclusive Test, 42 S. CAL. L. REv. 444 (1969) (citing figures from a 1964 survey of the federal system) slightly less than 9 percent of all defendants make the motion for a pre-trial psychiatric examination-which is apparently granted as a matter of course in many cases. See Kaufman, supra note 13, at 474-76. (2) Of those defendants examined, the great majority are found competent to stand trial. See Association of the Bar of the City of New York, Special Committee on the Study of Commitment Procedures and the Law Relating to INcompetents, Second Report, Mental Illness, Due Process and the Criminal DeFENDANT 88-89 (1968); Bacon, supra at $445 \mathrm{n.7}$ (72\% in the federal systein); Rosenberg, Competency for Trial-Who Knows Best?, 6 CRIM. L. BulL. 577, 578 (1970) (slightly over $90 \%$ in Massachusetts). (3) Presumably a high proportion of these defendants in tum plead guilty. According to Heberling, supra note 2, at 137, "roughly 90\%" of all criminal defendants plead guilty. Thus, it would seem that Sieling may affect a significant number of criminal defendants.

By eliminating the indefinite commitment of defendants who are incompetent to stand trial, Jackson v. Indiana, 406 U.S. 715 (1972), discussed supra note 13, will both reduce the number of defendants presently confined and encourage a number of defendants to plead incompetence who would otherwise have been deterred from so pleading by the prospect of indefinite commitment. See Comment, An End to Incompetency, supra note 13, at 572-74. Cf. Chernoff \& Schaffer, supra note 16, at 520. However, that decision will have little effect, if any, on the number of already convicted defendants who may seek relief under the rule of Sieling because Jackson governs the cases of those found incompetent to stand trial, whereas Sieling concerns those found competent who have subsequently pleaded guilty.

104. See, e.g., Pate v. Robinson, 383 U.S. 375 (1966); Lee v. Alabama, 386 F.2d 97 (5th Cir. 1967). Under this "right to a hearing" theory the reviewing court can make a nunc pro tunc determination of competency if the record can be adequately reconstructed and the lapse of time is not too great, see, e.g., People v. Hudson, 19 N.Y.2d 137, 225 N.E.2d 193, 278 N.Y.S.2d 593 (1967). Otherwise the defendant is entitled to a new trial, Lee v. Alabama, 386 F.2d 97, 105 (5th Cir. 1967); United States ex rel. Cole v. Follette, 301 F. Supp. 1137, 1149-50 (S.D.N.Y. 1969). After the defendant demonstrates that the original trial court had reason to doubt his competence, the burden is shifted to the state to prove that the defendant had been competent at trial. Thus the defendant need not prove actual incompetence. People v. Thompson, 36 III. 2d 332, 223 N.E.2d 97 (1967).

105. See, e.g., Bostic v. United States, 298 F.2d 678 (D.C. Cir. 1961); Taylor v. Umited States, 282 F.2d 16 (8th Cir. 1950). Under the approach of these cases it is not necessary that the court have been put on notice of the defendant's mental condition; his appearance of sanity and failure to raise the issue at trial do not bar relief. Taylor v. United States, 282 F.2d at 22 . However, the petitioner must prove his incompetence under this approach by a preponderance of the evidence. Crail v. United States, 430 F.2d 459 (10th Cir. 1970). See generally Schoeller v. Dunbar, 423 F.2d 1183, 1189-91 (9th Cir.), cert. denied, 400 U.S. 834 (1970) (Hufstedler, J., dissenting). See also Swadron, Collateral Attack of Federal Convictions on the Ground of Mental Incompetency, 39 TEMPLE L.Q. 117 (1966). See note 13 supra. 
competence to proceed, however, was binding unless found to be clearly erroneous. ${ }^{106}$ The result after Sieling is that even in cases in which the court in reliance on existing law took care to determine whether the defendant was competent to stand trial under the "understand and assist" standard, a defendant may be able to reopen his case; he need only prove that he had not been specifically found competent to plead guilty in order to receive review. Where it is not possible to make a retroactive determination of lis competence to plead guilty, the defendant will be entitled to a new trial, ${ }^{107}$ which for many defendanls may resuli il release rather than retrial.

\section{CoNCLUSION}

The issues raised in Sieling invite a general inquiry into the adequacy of the common law test of competence to stand trial and its application to the guilty plea and the waiver of constitutional rights. While the standard of competence adopted by the court does provide an essential element heretofore lacking in the assessment of competence-a requirement that a defendant be able to make rationally the decisions necessary to both a plea of guilty and a valid waiver of constitutional rights-it may be argued that the court relied on an overbroad reading of $W$ estbrook $\mathrm{m}$ erecting the requirement that this standard be used to judge the validity of all constitutional rights. Furthermore, having imposed this standard of competence on the entry of a guilty plea, the court failed to consider the possibility that this standard should also apply to the determination of the defendant's competence to stand trial. One practical effect of this limited application of the standard may be to create a class of semi-competent defendants who are competent to stand trial but incompetent to plead guilty, and will therefore be ineligible for the nore lenient treatment resulting from the plea bargaining process. ${ }^{108}$ On the other hand, Sieling may also furnish convicted defendants who waived one or more rights a technical basis for obtaining review. ${ }^{109}$ To avoid such results, it is strongly recommended that this new decisional standard be imcorporated into the standard for competence to stand trial, thereby protecting the volitionally incompetent defendant from the crimimal process as well as from an involuntary plea, while at the same time avoiding the probleins inherent in a dual standard of competence.

106. See Hanson v. United States, 406 F.2d 199 (9th Cir. 1969); Krupnick v. United States, 264 F.2d 213, 217 (8th Cir. 1959); Hill v. United States, 223 F.2d 699 (6th Cir.), cert. denied, 350 U.S. 867 (1955).

107. See Pate v. Robinson, 383 U.S. 375 (1966).

108. See notes 98-101 supra and accompanying text.

109. See notes 103-07 supra and accompanying text. 